\title{
REDEFINISI PERAN GURU MENUJU PENDIDIKAN ISLAM BERMUTU
}

\author{
Muhammad Saleh', Ahmad Edwar ${ }^{2}$, Maratusyolihat ${ }^{3}$ \\ STAI. KH. Abdul Kabier Serang-Banten \\ muhmadsaleh024@gmail.com, ahmadedwar9@gmail.com, \\ maratusyolihatihat@gmail.com
}

\begin{abstract}
The dichotomy of secular science and religious science changes the mindset of the Muslim community in religion. From the classical period, which saw Islam as a comprehensive teaching, it has turned into an understanding that views Islam as a religion that is only ritual oriented. It is understood that education is a process that has continuity and is consciously carried out to prepare a generation that has balanced knowledge and values. On the other hand, the negative impact of modern life cannot be avoided by modern humans, especially from the aspect of education. For this reason, various elements in education must continue to maintain existing linkages to achieve predetermined goals. Low participation and public concern for the advancement of the world of education must end, along with the realization of the concept of school based management or SBM. Another aspect that must be prepared is the quality of teachers. Conceptually, teachers have three functions, namely cognitive, moral and innovative. In order to become an ideal figure in Indonesia, teachers must meet eight indicators, namely theological principles, formal principles, functional principles, cultural principles, comprehensiveness principles, substantial principles, social principles and identity principles.
\end{abstract}

Keywords: Educational Problems, Teacher Role, and Educational Philosophy Reformulation

\section{ABSTRAK}

Dikotomi seculer science dan religious science merubah polapikir masyarakat muslim dalam beragama. Dari periode klasik yang memandang Islam sebagai ajaran komprehensif, berubah menjadi sebuah pemahaman yang memandang Islam sebagai agama yang hanya berorientasi kepada ritual. Dipahami bahwa pendidikan adalah proses yang memiliki continuity dan secara sadar dilakukan untuk mempersiapkan generasi yang memiliki pengetahuan dan nilai secara seimbang. Di sisi lain, dampak negatif dari kehidupan modern tidak dapat dihindari lagi oleh manusia modern, terutama dari aspek pendidikan. Untuk itu, berbagai unsur pada pendidikan harus terus menjaga keterkaitan yang telah ada untuk mencapai tujuan yang telah ditetapkan. Partisipasi dan kepedulian masyarakat yang masih rendah terhadap kemajuan dunia pendidikan harus diakhiri, seiring realisasi konsep school based management atau SBM. Aspek lain yang harus disiapkan adalah kualitas guru. Secara konsepsional, guru memiliki tiga fungsi, yaitu kognitif, moral dan inovatif. Agar menjadi sosok ideal di Indonesia, guru harus memenuhi delapan indikator, yaitu prinsip teologis, prinsip formal, prinsip fungsional, prinsip kultural, prinsip komprehensivitas, prinsip subtstansial, prinsip sosial dan prinsip identitas.

Kata Kunci: Problematika Pendidikan, Peran Guru, dan Reformulasi Filsafat Pendidikan 


\section{PENDAHULUAN}

Dalam periode emas, peradaban Islam telah menunjukkan diri sebagai suatu kekuatan sosial-politik yang mampu menguasai dua per tiga wilayah di bumi ini. ${ }^{1}$ Peradaban yang mulai dirintis sejak zaman Nabi Muhammad SAW tersebut, perlahan tetapi pasti, berjalan menembus dan menguasai pusat-pusat peradaban yang ada di sekitar Semenanjung Arab. Byzantium dan Persia (Iran), dua kekuatan raksasa yang ketika itu sangat berpengaruh dalam dunia internasional, ternyata tidak mampu membendung arus deras peradaban Islam yang mulai dikembangkan oleh Dinasti Umayyah dan mencapai masa puncak kejayaannya pada periode Dinasti Abasiyyah.Meskipun suksesi kepemimpinan dari Dinasti Umayyah ke Dinasti Abasiyyah masih menyisakan berbagai masalah, yang mencapai puncaknya ketika Abdurrahman al-Dakhil mendirikan Dinasti Umayyah II di Andalusia Spanyol, namun Dinasti Abasiyyah tetap menunjukkan eksistensi dan supremasinya dalam membangun peradaban Islam.

Kesuksesan Dinasti Abasiyyah ini merupakan hasil dari perhatian yang serius terhadap pertumbuhan dan perkembangan dunia pendidikan.Ketika itu, pendidikan lebih tepat disebut sebagai tink tank peradaban. Di samping sebagai instrumen terpenting dalam membangun dan menjaga eksistensi sebuah peradaban, pendidikan juga merupakan aspek teologis yang harus dilaksanakan oleh semua orang Islam. Artinya, menuntut ilmu dalam pendidikan untuk menjadi orang yang mampu menunjukkan keislamannya dan memiliki integritas moral dan sosial yang tinggi, hukumnya adalah wajib 'ain bagi setiap Muslim. Dalam QS. al-Mujadalah: 11, Allah SWT sendiri telah menunjukkan komitmen-Nya untuk mengangkat derajat orang-orang yang berilmu. Meski demikian, pendidikan akan mengikuti proses perjalanan historis yang pasti mengalami maju mundur dalam perkembangannya. Kemunduran dalam dunia pendidikan ini, secara disengaja atau tidak, akan mengakibatkan kemunduran peradaban Islam itu sendiri. Inilah yang oleh Mughni diidentifikasikan sebagai sebuah awal dari abad pertengahan yang gelap bagi perkembangan peradaban Islam. ${ }^{2}$ Kemunduran peradaban Islam yang secara terus menerus berimplikasi kepada kemunduran peradaban Islam dan dalam waktu cukup lama, telah mengakibatkan berbagai kekalahan masyarakat muslim ketika menghadapi kemajuan bangsa Barat. Arus deras modernisme di Barat ini menyebabkan mereka, dalam beberapa hal, lebih maju dari masyarakat muslim. ${ }^{3}$

Sedangkan masyarakat muslim sendiri, masih berjuang sekuat tenaga dalam merespon modernisme tersebut. Di satu pihak, masyarakat muslim ini menerima gagasan modernisme, sedangkan di pihak lain menunjukkan penolakan terhadap gagasan tersebut. Sikap mendua dari masyarakat muslim ini merupakan refleksi dari adanya keinginan untuk tetap berpegang teguh kepada ajaran agama yang diyakini kebenarannya (Islam), disamping tidak adanya kemampuan dari masyarakat muslim itu sendiri dalam mewujudkan independensinya terhadap kemajuan ilmu pengetahuan dan teknologi. Oleh karena itu, sikap menolak (resistance) dari masyarakat muslim terhadap modernisme

Barat lebih disebabkan adanya self sufficiency, yaitu kepercayaan bahwa doktrin Islam sudah cukup untuk menjawab berbagai problematika dalam peradaban manusia, tidak lagi membutuhkan yang lain. Di samping itu, doctrin

\footnotetext{
${ }^{1}$ Harun Nasution, Pembaharuan Dalam Islam (Jakarta : Bulan Bintang, 1992), 13.

22 Syafiq A. Mughni, Dinamika Intelektual Islam Pada Abad Kegelapan (Surabaya : LPAM, 2002), 54-57.

3 Karen Armstrong, A History of God (New York : Ballantine Books, 1993), 293.
} 
finality, yang berasumsi bahwa doktrin Islam merupakan ajaran terakhir dan terlengkap, tidak boleh dikurangi ataupun ditambah, telah menjadi sebuah mentalitas masyarakat muslim. Sedangkan sikap menerima (receptive) masyarakat muslim terhadap modernisme Barat lebih disebabkan adanya absolutisme dari modernisme itu sendiri, menjadi sesuatu yang tidak bisa dipungkiri. Meskipun demikian, respon yang diberikan dalam menerima gagasan modernisme itu juga bervariasi, mulai dari yang selektif, liberal hingga sekuler. ${ }^{4}$

Kedua respon ini kemudian melahirkan dua kutub saling bertentangan, sehingga sebagian masyarakat yang lain mengambil jalan tengah (middle roads), dalam rangka meredam "perang dingin" ini. Ketiga respon masyarakat muslim dalam menjawab modernisme Barat tersebut juga memiliki implikasi tidak kecil dalam perkembangan pendidikan. Artinya, penyelenggaraan pendidikan ketika itu lebih menunjukkan berbagai corak aliran masing-masing kelompok. Dari perbedaan ini, dikotomi modern dan tradisional mulai mengemuka dalam sistem pendidikan. ${ }^{5}$ Dikotomi itu sendiri, di sisi lain, juga mendorong sebagian kelompok untuk berupaya mengkombinasikan keduanya, sebagai middle roads, yang berupaya untuk menutupi berbagai kekurangan dari kedua sistem yang ada sekaligus mempertahankan nilai-nilai positif dari keduanya.Disadari bahwa kemunduran peradaban Islam juga disebabkan adanya perhatian yang tidak seimbang antara secular science dan religious science, maka masyarakat muslim berupaya untuk mengakhiri itu semua. Dikotomi itu sendiri tidak bisa dilepaskan dari upaya penetrasi intelektual bangsa Barat. ${ }^{6}$

Dengan dalih modernisasi, berbagai upaya telah dilakukan untuk mencapai ending adanya pemisahan yang jelas terhadap esensi ilmu. Faktor ini memberikan kontribusi terhadap pembentukan pola pikir masyarakat muslim ketikaitu dalam memandang ilmu dari perspektif keyakinan agamanya (baca : Islam).Oleh karena itu, dikotomi secular science dan religious science ini dalam perkembangannya mampu merubah pola pikir masyarakat muslim dalam beragama. Dari periode klasik yang memandang Islam sebagai suatu ajaran komprehensif, yang mengatur manusia dalam berinteraksi secara vertikal maupun horisontal, berubah menjadi sebuah pemahaman yang memandang Islam sebagai agama yang hanya berorientasi kepada ritual manusia kepada Tuhannya. ${ }^{7}$

Permasalahan-permasalahan terkait dengan kehidupan sehari-hari manusia secara langsung dan kurang bersifat transendental, dianggap sebagai "sisi lain" dari ajaran agama sehingga kurang begitu penting untuk dikaji. Pemahaman seperti ini memiliki konskuensi logis terhadap perkembangan ilmu ketika itu, yaitu berorientasi kepada pengembangan religious science, seperti fiqh, tauhid, hadits, tafsir, tarikh dan sebagainya. Sedangkan secular science, seperti logika, filsafat, kimia, kedokteran, matematika, farmasi, biologi, fisika dan sebagainya, diasumsikan sebagai sesuatu yang tidak wajib dikembangkan oleh masyarakat muslim. Dikotomi ilmu dalam masyarakat muslim ini, pada masa sekarang, telah membawa implikasi besar bagi kultur masyarakat itu sendiri. Pemahaman-

${ }^{4}$ Osman Bakar, Tauhid dan Sains, terj. Yuliani Liputo (Bandung : Pustaka Hidayah, 1994), 220-221.

5 Ali Ashraf dan Sajjad Husain, Crisis in Muslim Education (Jeddah : King Abdulaziz University Press, 1979), 11-16. Bandingkan dengan Mukani, Pergulatan Ideologis Pendidikan Islam (Malang: Madani Media, 2011).

${ }^{6}$ Jeanne S. Mintz, Muhammad, Marx, Marhaen; Akar Sosialisme di Indonesia, terj. Zulhilmiyasari (Yogyakarta : Pustaka Pelajar, 2002), 21-23.

${ }^{7}$ Abdul Muta'al al-Sha'idy, Al-Mujaddidun fil Islam (Kairo : Darul Hamam lil Thaba'ah, tt), 5 . 
pemahaman yang diturunkan dari dikotomi tersebut seolah telah menjadi sebuah dogma yang harus diwariskan kepada generasi selanjutnya. Di sisi lain, pendidikan sekarang lebih menunjukkan orientasinya dalam memberikan pengetahuan (transfer of knowledge) kepada generasi selanjutnya, sedangkan pewarisan nilai-nilai luhur yang dilakukan melalui pendidikan (transfer of values) kurang memperoleh perhatian dalam pelaksanaannya. Ini sebenarnya menjadi tugas besar untuk mengembalikan pendidikan kepada posisi ideal, disamping sebagai salah satu upaya maksimal untuk menjawab problematika yang disebabkan adanya miss-understanding yang dilakukan terhadap esensi ilmu, yang berujung kepada dikotomi antara secular science dan religious science di atas.Upaya-upaya maksimal yang telah dilakukan ini tidak bisa dilepaskan dari realita di lapangan, yang pada masa-masa sekarang ini justru menunjukkan urgensi pelaksanaannya. Artinya, masalah-masalah yang muncul dan berkaitan erat dengan dunia pendidikan pada masa sekarang, mengharuskan pencarian solusi secara tepat dan efektif. Jika tidak, maka berbagai problematika yang ada akan menjadi beban lebih berat bagi generasi penerus. Oleh karena itu, peran pendidikan sangat signifikan dalam melahirkan generasi berkualitas yang memiliki kompetensi tertentu. Lebih jauh dipahami bahwa pendidikan merupakan sebuah proses yang memiliki continuity dan secara sadar dilakukan untuk mempersiapkan generasi yang memiliki pengetahuan dan nilai secara seimbang.

Jika mampu mengevaluasi terhadap program pendidikan yang telah dilaksanakan selama ini, maka justru keseimbangan (balancing) dalam proses pendidikan inilah yang sekarang menjadi masalah besar. Berbagai kasus yang menjadi sorotan masyarakat dan berkaitan erat dengan dunia pendidikan, seperti perkelahian antar siswa, komersialisasi pendidikan, kualitas guru yang masih rendah, marginalisasi masyarakat miskin dalam menikmati pendidikan dan sebagainya, merupakan rangkaian masalah yang bermuara kepada satu pertanyaan penting, sudah pincangkah pendidikan yang telah dilaksanakan selama ini?

\section{PEMBAHASAN \\ Prinsip bagi Pendidik}

Pendidikan, dalam perspektif Indonesia, merupakan aset paling mahal dalam membangun diri dan menjaga eksistensi. Harapan-harapan terhadap sosok "manusia prospektif" merupakan suatu hal wajar ketika melihat kompleksitas problematika dunia modern. Ekspektasi tinggi terhadap keberhasilan pendidikan untuk melahirkan manusia yang mampu mengemban tanggung jawab dan melaksanakan tongkat estafet kepemimpinan, mendorong sebuah bangsa untuk tidak pelit dalam mengalokasikan anggaran kepada sektor pendidikan.Di sisi lain, dampak negatif dari kehidupan modern tidak dapat dihindari lagi oleh manusia modern, terutama dari aspek pendidikan. Berawal dari keberadaan something lost dalam diri yang mendorong pencarian spiritual dalam dogma agama, manusia modern telah berupaya untuk mengakhiri split personality yang dialami akibat terlalu mendewakan kekuatan rasiomaterialisme. Dengan pemahaman yang tidak sempit seperti ini, manusia modern merupakan ciptaan Tuhan yang diharapkan mampu mewujudkan peran strategis sebagaikhalifah fil 'ardh maupun 'abdullah. Namun, dalam mencari solusi terhadap berbagai problematika yang dihadapi pendidikan pada masa sekarang, mayoritas manusia modern masih terjebak kepada permasalahan-permasalahan teknis dan parsial. Kesadaran bahwa pendidikan merupakan kunci dalam membahas dan memecahkan berbagai masalah dalam bidang ekonomi, hukum, politik dan HAM, ternyata belum lahir di 
tengah masyarakat Indonesia. Maka, wajar jika bangsa ini masih sulit untuk keluar dari keterpurukan akibat krisis multidimensi sejak pertengahan 1997 silam.

Dalam konteks kekinian, pendidikan sebenarnya mampu memberikan jawaban terhadap berbagai masalah yang sedang dihadapi bangsa ini, meskipun masih membutuhkan waktu untuk melihat kualitas outcome pendidikan dalam menyelesaikan masalah-masalah tersebut. Jika saat ini bangsa Indonesia sedang gencar memerangi korupsi dan penyalah-gunaan narkoba, maka pendidikan sebenarnya mampu mengakomodasikan hal ini kedalam kurikulum pendidikan. Begitu juga dengan kerusakan alam, budaya malas, rendahnya kualitas sumber daya manusia dan sebagainya. Pada posisi ini pendidikan diharapkan mampu mewujudkan peran dan fungsinya tersebut dengan baik.Pendidikan merupakan aspek kehidupan yang hasilnya tidak langsung dilihat, membutuhkan waktu lama dengan disertai analisis tajam. Berbagai unsur pada pendidikan harus terus menjaga keterkaitan yang telah ada untuk mencapai tujuan yang telah ditetapkan. Partisipasi dan kepedulian masyarakat yang masih rendah terhadap kemajuan dunia pendidikan, yang lebih disebabkan kultur masyarakat yang masih menganggap bahwa tanggung jawab pendidikan murid menjadi tugas pihak sekolah semata, harus segera diakhiri. Hal ini sangat ditekankan mengingat masyarakat merupakan pihakyang paling berkepentingan kepada eksistensi pendidikan (stakeholders), terutama dalam mewariskan nilai-nilai luhur yang terdapat di dalam masyarakat dan mengembankan kemajuan ilmu pengetahuan dan teknologi yang telah diraih.

Peran serta masyarakat terhadap kemajuan pendidikan ini semakin dirasakan seiring realisasi konsep school based management atau SBM.Aspek utama lain yang harus segera dipersiapkan dengan baik oleh bangsa ini adalah kualitas guru. Vilfredo Pareto, dalam Social Elites and Their Circulation, menyatakan bahwa setiap masyarakat akan diperintah oleh sekelompok kecil orang yang memiliki kekuasaan dan politik secara mutlak. Kelompok ini mampu menduduki jabatan strategis dan tinggi pada semua lapisan masyarakat. Mereka terdiri dari para mekanik, advokat, preman sampai dengan para gundik. Kelompok inilah yang disebut dengan elite. Pada teori elit dan sirkulasi elit itu, Pareto menawarkan konsep yang disebut dengan dua lapisan kelas sosial masyarakat, yaitu lapisan atas yang terdiri dari kelompok elit yang sedang memerintah (governing elite) dan elit yang tidak memerintah (non-governing elite). Sedangkan lapisan kedua adalah kelas bawah yang terdiri dari lapisan kelompok masyarakat yang dipimpin (non-elite). ${ }^{8}$

Dalam konteks pendidikan, guru sebenarnya memiliki posisi yang sangat signifikan dalam melahirkan generasi muda yang prospektif dan berkarakter, sebagaimana amanat yang tercantum pada Pembukaan UUD 1945. Dengan berposisi sebagai pendidik, guru memiliki tugas ekstra untuk membentuk outcome yang berkualitas, tidak sekedar outputdan harus siap berkompetisi menghadapi bangsa-bangsa lain dalam percaturan global.Secara konsepsional, guru memiliki tiga fungsi, yaitu kognitif, moral dan inovatif. Fungsi pertama mengharuskan guru untuk mentransferkan teori-teori ilmu pengetahuan yang dimiliki kepada para muridnya. Fungsi moral mengandung makna guru harus mampu menjaga perilaku dari muridnya, sekaligus menjadi suri teladan (uswatun hasanah) bagi para muridnya. Sedangkan fungsi inovatif berarti guru harus memiliki daya kreativitas

8 Baca Mukani, "Mendamba Guru Ideal Perspektif Kota Santri,” Rakyat Post, 16 Juli $2009,2$. 
dalam meningkatkan kualitas proses pembelajaran yang dilaksanakan bersama muridnya tersebut. ${ }^{9}$

Sebagai negara dengan penduduk mayoritas beragama Islam, Indonesia harus mampu menunjukkan eksistensi dan berbicara banyak dalam dunia internasional melalui sistem pendidikan yang dimiliki. Grand design dan mind set tersebut akan bisa terwujud jika kualitas guru mampu bersaing secara kompetitif dengan negara-negara lain. Untuk itu, diperlukan kualifikasi substantif sebelum menjadi guru, tidak sekedar persyaratan normatif-administratif sebagaimana yang telah menjadi sebuah fenomena sampai detik ini.Agar menjadi sosok ideal di Indonesia, guru minimal harus memenuhi delapan prinsip sehingga mampu memberikan kontribusi positifnya bagi peningkatan kualitas pendidikan di negeri ini. Pertama, prinsip teologis. Sebagai sosok pendidik, guru sudah seharusnya memiliki komprehen-sivitas dalam menginterpretasikan doktrin agama yang diyakini, tidak sekedar belajar secara parsial dan eksklusif, yang kemudian diimplementasikan dan diinternalisasikan kedalam kehidupan keseharian. Upaya ini merupakan langkah fundamental yang sangat penting bagi guru dalam melahirkan generasi muda penerus bangsa yang prospektif, dengan disertai dedikasi yang tinggi tentunya. Prinsip teologis juga diharapkan mampu memotivasi guru untuk memiliki check and balancens dari ketiga ranah keberagamaan yang dimiliki, baik sistem kepercayaan (credo), sistem peribadatan (ritual) maupun sistem perilaku (moral).Kedua, prinsip formal. Guru, secara normatif, harus memiliki kualifikasi pendidikan minimal sarjana S-1 atau D-4, sebagaimana diatur dalam Pasal 8 UU Nomor 14 Tahun 2005 Tentang Guru dan Dosen. ${ }^{10}$

Namun berdasar data DirektoratJenderal PMPTK Departemen Pendidikan Nasional Republik Indonesia, pada awal tahun 2010 terdapat 2.374.722 guru di seluruh Indonesia. Dari jumlah itu, sebanyak 1.427.667 guru (60,11 persen) masih berijazah SLTA, sebanyak 930.804 guru (39,19 persen) berijazah sarjana, 16.196 guru $(0,68$ persen) sudah berijazah magister dan baru 55 guru berijazah doktor. Menurut rencana, pada tahun 2014 nanti, guru yang sudah harus berijazah sarjana sebesar 100 persen pada jenjang SLTA, 97 persen pada jenjang SLTP dan 95 persen pada jenjang SD. Jika mau berkaca secara teliti dari kasus para guru Malaysia, yang pada 1960-an para pemudanya masih menimba ilmu (kuliah) di Indonesia, namun Malaysia sekarang sudah meninggalkan Indonesia dalam beberapa segi. Sedangkan Indonesia, setelah tahun 2000-an, hanya mampu mengirimkan generasi mudanya ke Malaysia, namun hanya sebagai tenaga kasar. Ternyata, guru di Malaysia harus berasal dari PTN, tidak boleh dari PTS. Tidak seperti di Indonesia yang carut marut dengan praktik jual beli ijazah instant, meskipun sudah dikeluarkan Surat Edaran dari Direktorat Jenderal Dikti Departemen Pendidikan Nasional Republik Indonesia Nomor 595/D/T/2007 tanggal 27 Pebruari 2007 yang melarang praktik kuliah kelas jarak jauh dan kuliah dua hari atau week end. ${ }^{11}$

Ketiga, prinsip fungsional. Dalam melaksanakan tugas, guru harus dilandasi dengan semangat dedikasi yang tinggi Untuk menunjukkan pengabdian kepada ibu pertiwi, tidak kemudian mudah terjebak kepada kepentingan pragmatis

\footnotetext{
${ }^{9}$ Mukani, “Minim Karya Tapi Karya Gelar,” Rakyat Post, 1 Desember 2011, 2.

${ }^{10}$ Mukani, "Guru Bermutu dari Program Master Teacher," Majalah Media, Maret 2013, $30-31$.

${ }^{11}$ Nurul Yani, "Ijasah Instan dan Mental Pragmatis Guru," Majalah Media, Desember 2013, 63-64.
} 
yang hanya sekedar bekerja kemudian memperoleh gaji. Di sisi lain, idealisme, kedisiplinan, kompetensi, kejujuran, progresivitas, keikhlasan, kesabaran dan komitmen yang dimiliki guru harus tetap dikembangkan dan disertai dengan upaya-upaya konstruktif untuk memajukan pendidikan di Indonesia. Dalam kehidupan berbangsa, inti dari krisis multidimensi yang dihadapi bangsa Indonesia sejak 1997 silam sebenarnya adalah masih melandanya krisis mental yang dialami rakyat di negeri ini. Pada perspektif pendidikan, sudah saatnya guru menjadi suri teladan, minimal bagi komunitas di sekitarnya, tidak lantas kemudian melakukan perbuatan yang bisa merendahkan martabatnya sendiri, sebagaimana yang dilakukan selama ini oleh sebagian oknum guru. Keempat, prinsip kultural. Budaya membaca, menulis dan meneliti masih sangat minim dilakukan oleh para guru. Kurniawan Muhammad menulis bahwa dalam satu hari, orang Indonesia hanya melaksanakan salah satu dari ketiga aktivitas tersebut sebanyak satu persen, sedangkan 99 persen lainnya dihabiskan dengan budaya tutur (lisan). Padahal, jika mampu mengkaji historisitas bangsa-bangsa beradab di bumi ini, mereka mampu meraih kemajuan karena didukung ketiga aktivitas tersebut, terutama dalam meneliti. Pada aspek lain, karena guru dapat dikategorikan sebagai sebuah jabatan akademis, maka guru dituntut memiliki kultur intelektualisme dalam semua kesehariannya, seperti ilmiah, non-konservatif, berwawasan global, mandiri, rasional, memahami filosofi sains, dan sebagainya. ${ }^{12}$

Kelima, prinsip komprehensivitas. Konsep ini akan mendorong guru untuk melakukan pemaknaan ulang (re-interpretation) terhadap substansi pendidikan itu sendiri. Meminjam istilah Henry A. Giroux, guru harus memberikan kritik konstruktif kepada kurikulum yang telah berjalan selama ini, tidak sekedar mengimplementasikannya. ${ }^{13}$

Konsep ini memperoleh "angin segar" ketika dipahami substansi Kurikulum Tingkat Satuan Pendidikan (KTSP) Tahun 2006 yang memberikan peluang kepada guru untuk lebih menjabarkan kurikulum, disesuaikan dengan situasi dan kondisi dari masyarakat sekitar. Jika mau jujur, sebenarnya masih banyak kearifan lokal (local genous) yang belum mampu digali dari daerahdaerah di Indonesia untuk kemudian diangkat sebagai sebuah universalitas nilai yang berlaku di semua daerah. Hal ini sesuai dengan substansi pendidikan yang tidak hanya memberikan teori-teori sains (transfer of

knowledge), tetapi juga berusaha mewariskan nilai-nilai luhur bangsa (transfer of values) agar lestari dan terjaga orisinalitasnya melalui implementasi kongkret dalam kehidupan sehari-hari murid.

Keenam, prinsip substansial. Sebagai sebuah profesi yang hendak disejajarkan dengan berbagai profesi yang sudah menjanjikan lainnya, seorang guru harus memiliki tiga keahlian dasar ketika mengajar, yaitu materi, metodologi dan psikologi. Keahlian pertama berkaitan dengan apa yang harus diberikan kepada murid, yang hal ini tentu saja mengharuskan guru untuk mengikuti perkembangan sains dengan cermat. Keahlian kedua berhubungan dengan bagaimana teknik membelajarkan murid agar senang dalam belajar, sehingga hal ini mendorong guru untuk menggunakan berbagai metode mengajar secara kreatif dan tidak monoton. Keahlian terakhir berkaitan dengan kapan proses

${ }^{12}$ Mukani, "Ironi, Pendidik Jombang Menjiplak Disertasi," Majalah Suara Pendidikan, No. 6, Pebruari 2013, 36-37.

${ }^{13}$ Mukani, "Guru Profesional Tak Cuma Tumpuk Portofolio," Majalah Media, Oktober 2012, 34-336. 
pembelajaran murid itu dilaksanakan. Artinya, guru harus memiliki pemahaman yang komprehensif terhadap kondisi kejiwaan dari murid yang akan dibelajarkannya. Secara teoritis, kualifikasi dari prinsip substansial ini sudah diperoleh semua guru ketika menimba ilmu di perguruan tinggi. Namun, realita di lapangan tidak jarang bertolak belakang. Banyak murid yang masih mengeluhkan metode mengajar guru yang terfokus kepada ceramah, bahkan mendikte. Guru ideal harus mampu melakukan introspeksi dari proses pembelajaran yang telah dilaksanakan selama ini, tidak justru mudah puas terhadap hasil yang telah diperoleh. Hasil intropeksi itu kemudian direfleksikan dalam bentuk perbaikan teknik mengajar, yang kemudian dibuktikan dengan meningkatnya minat murid untuk mengikuti pelajaran, disebabkan karena guru yang mengajar memiliki sifat menarik dan menyenangkan. ${ }^{14}$

Ketujuh, prinsip sosial. Dalam perspektif pengembangan masyarakat, di samping sebagai pendidik murid dalam lingkungan pendidik, guru juga harus mampu memberikan kontribusi positif bagi pengembangan masyarakat di sekitarnya (community organizer). Langkah kongkret pertama yang harus dilakukan guru adalah melakukan rekonstruksi dari komunitas di sekelilingnya menjadi sebuah "laboratorium nyata" dalam mengimplementasikan nilai-nilai edukatif yang telah diterima saat kuliah. Guru juga harus mampu menjalin komunikasi yang aktif dengan semua lapisan masyarakat dengan berbagai variannya itu. Guru ideal tidak boleh memiliki eksklusivitas dalam berinteraksi dengan anggota masyarakat lain.

Kedelapan, prinsip identitas. Budaya yang masih dilestarikan oleh masyarakat Indonesia, harus mampu dikaji secara seksama oleh guru untuk kemudian diimplementasikan nilai-nilai yang terkandung di dalamnya sebagai sebuah identitas tersendiri yang bersumber dari local genous. Dengan demikian, di tengah percaturan global, diharapkan generasi muda sekarang masih tetap memiliki identitas. ${ }^{15}$

Jika kedelapan prinsip di atas mampu dilaksanakan secara konsisten dan kontinyu oleh para guru di Indonesia, maka tidak mustahil akan lahir banyak guru ideal di negeri ini. Pada akhirnya, kualitas guru yang terus meningkat ini akan berkorelasi positif terhadap perbaikan kualitas pendidikan di Indonesia.

\section{Reformulasi Filsafat Pendidikan}

Masa modern, yang kemudian memunculkan gelombang filsafat modern, menurut mayoritas sejarahwan diawali dari titik tolak kesadaran manusia dalam mersepon perkembangan ilmu pengetahuan dan teknologi, yang diaktualisasikan dalam masa enlightenment, atau lebih tepatnya adalah masa kebangkitan atau renaissance. Pada masa ini, individualismetelah diletakkan manusia modern sebagai pusat dunia dengan menekankan kehidupan manusia sebagai sentral dari realitas (anthropocentris). Sebagai proyek enlightenment, kehidupan modern telah diformulasikan oleh para filosofnya sejak abad XVIII Masehi dengan berupaya meraih penguasaan ilmu pengetahuan objektif, tanpa mengenal lelah. Dengan menekankan hukum universalistik yang sesuai dengan logika internal manusia dan pentingnya dasar moralitas, kehidupan modern juga mengeksplorasi berbagai

${ }^{14}$ Mukani, "Character Education di Indonesia,” Jurnal Islamica, Vol. 1 No. 2, Maret 2007 (Surabaya : Program Pascasarjana IAIN Sunan Ampel Surabaya), 146-161.

${ }^{15}$ Mukani, "Sertifikasi, Menuju Guru Profesional?," Kompas, 1 Oktober 2007, 6. 
potensi kognitif yang dimiliki manusia dan mencapai titik puncaknya pada penggunaan ilmu pengetahuan itu sendiri bagi kepentingan praktis manusia. ${ }^{16}$

Dengan upaya itu semua, banyak aktivitas manusia yang menjadi lebih mudah pelaksanaannya dikarenakan perkembangan ilmu pengetahuan dan teknologi yang telah sangat maju. Di sisi lain, berbagai problematika yang sedang dihadapi pendidikan di Indonesia saat ini sebenarnya bermuara kepada semakin jauhnya manusia dari titik axis dalam dirinya. Manusia modern lebih banyak memberikan porsi waktu dan perhatiannya kepada berbagai masalah yang bersifat normatif-teknis, daripada harus memikirkan ulang hal-hal prinsip dan fundamental. Karena memiliki paradigma pemikiran pragmatis seperti ini, menurut John Naisbitt, manusia modern belum mampu menemukan jati dirinya secara holistis, sehingga berujung kepada semakin dirasakannya dampak dari something lost dalam dirinya. ${ }^{17}$

Berbagai problematika pendidikan merupakan suatu hal yang harus dihadapi. Berbagai dampak negatif kehidupan modern harus diminimalisasi dalam berbagai sektor kehidupan manusia modern, termasuk pendidikan. Jika hal ini mampu dipahami secara cermat, maka yang menjadi tugas utama sekarang adalah upaya menampilkan pendidikan dalam konteks modern dengan visi baru yang mampu berperan aktif dan memiliki kontribusi signifikan dalam kancah modernitas itu sendiri. Dengan demikian, upaya merenungkan dan mencermati kembali terhadap substansi pendidikan yang dilaksanakan selama ini merupakan suatu keharusan, meliputi filsafat, teori dan kurikulum pendidikan. ${ }^{18}$

Hal ini perlu memperoleh tekanan yang lebih mengingat ketiganya adalah variabel yang harus ada dalam proses pendidikan, yang berfungasi memberikan arah dan model pendidikan itu sendiri.Filsafat pendidikan, dengan pola pemikiran yang radikal, sistematis, komprehensif dan ketat terhadap berbagai fenomena yang dihadapi, merupakan pendekatan pemikiran secara filosofis terhadap permasalahan dalam bidang pendidikan. ${ }^{19}$

Kelahiran filsafat pendidikan dilatarbelakangi adanya asumsi bahwa pendidikan merupakan sesuatu yang masih bersifat normatif, sehingga bertugas merumuskan kaidah-kaidah norma dan nilai yang akan menjadi tolok ukur untuk menilai perbuatan manusia. Oleh karena itu, dengan asumsi ini, pendidikan sangat berkaitan erat dengan ilmu-ilmu normatif, seperti agama, filsafat, kebudayaan dan sosiologi, yang semuanya bersumber dari way of life suatu masyarakat, kaidah fundamental negara dan tradisi kebudayaan bangsa.Namun, di sisi lain, asumsi yang lain juga harus diberikan, yaitu bahwa filsafat pendidikan lahir karena ilmu pendidikan merupakan ilmu praktis, maka tugas pendidikan sebagai aspek kebudayaan adalah menyalurkan dan melestarikan nilai-nilai yang terdapat di masyarakat untuk dikembangkan kearah tujuan yang lebih baik dan sempurna.

16 Jurgen Habermas, "Modernity: an Unfinished Project," dalam The Post-Modern Reader, ed. Charles Jencks (New York : St. Martins Press, 1992), 162-163.

${ }^{17}$ Dengan pemahaman seperti ini, diprediksi peran agama di masa mendatang semakin signifikan, sehingga kejayaan era agama pada Abad Pertengahan mampu menjadi new spirit untuk menjawab split personality manusia modern. Kebangkitan era agama ini diiringi kebangkitankebangkitan dalam bidang lain, seperti biologi, kebudayaan, globalisasi ekonomi, nasionalisme kultur, swastanisasi negara sejahtera, kepemimpinan wanita, kebangkitan wilayah Pasifik dan sikap individualisme. John Naisbitt dan Patricia Aburdence,Megatrend 2000 (London : Sidwick, 1990).

18 Ali Maksum dan Luluk Yunan Ruhendi, Paradigma Pendidikan Universal di Era Modern dan Post-Modern (Yogyakarta: Ircisod, 2004).

${ }^{19}$ Louis O Kattsoff, Pengantar Filsafat, terj. Soerjono Soemargono (Yogyakara: Tiara Wacana, 1994). 
Dengan demikian, asumsi kedua ini bersentuhan pula dengan agama, filsafat, tradisi kebudayaan dan kaidah fundamental negara, mengingat nilai-nilai tersebut bersumber dari aspek-aspek ini.Urgensi untuk melakukan reformasi terhadap filsafat pendidikan, sebagai dasar dari sistem pendidikan yang dilaksanakan di Indonesia selama ini, merupakan suatu keharusan. Hal ini didasarkan kepada kenyataan bahwa filsafat, dalam arti umum, merupakan dasar perilaku seseorang dan juga suatu bangsa. Filsafat merupakan upaya pemahaman terhadap objeknya secara mendalam (radical), sehingga dari upaya ini lahir tindakan-tindakan yang bertugas mengaktualisasikan pemikiran filsafat yang masih abstrak tersebut. Filsafat pendidikan, sebagi cabang filsafat yang memfokuskan diri kepada permasalahan pendidikan, diharapkan mampu memberikan dasar-dasar pemikiran dalam mendidik peserta didik untuk meraih kedewasaannya. $^{20}$

Peserta didik harus dilihat secara holistik, yang memiliki pengetahuan jasmani dan pengetahuan ruhani secara beriringan, tidak parsial sebagaimana yang terjadi pada masa sekarang. Keduanya harus dikembangkan oleh pendidikan secara seimbang. ${ }^{21}$ Berdasarkan hasil pemikiran-pemikiran filosofis terhadap berbagai problematika pendidikan masa sekarang, diharapkan adanya penyusunan teori pendidikan yang baru supaya pelaksanaan pendidikan lebih terarah dan sistematis dalam mewujudkan tujuannya. Teori pendidikan ini, yang diterapkan dalam sebuah kurikulum, harus dirumuskan dengan tetap mempertimbangkan berbagai aspek yang terdapat dalam pendidikan itu sendiri, seperti pendidik, peserta didik, kurikulum, fasilitas, manajemen, materi pembelajaran, dan sebagainya. Tanpa mengesampingkan sasaran-sasaran yang bersifat teknis dan jangka pendek, dengan berpijak dari filsafat pendidikan dan teori pendidikan yang telah dirumuskan, kurikulum tentu akan mengantarkan pencapaian tujuan pendidikan yang lebih menyeluruh dan luas. Akhirnya, upaya mencari formulasi yang baru dari filsafat pendidikan menjadi suatu keharusan sebelum membahas arah dan tujuan pendidikan itu sendiri.

\section{KESIMPULAN}

Berbagai konsekwensi bermunculan dari kehidupan modern. Di samping kemudahan bagi manusia dalam menyelesaikan berbagai aktivitas, kehidupan modern juga berdampak negatif. Dikotomi secular science dan religious science, sebagai salah satu studi kasus, merubah pola pikir masyarakat muslim dalam beragama. Dari periode klasik yang memandang Islam sebagai ajaran komprehensif, berubah menjadi sebuah pemahaman yang memandang Islam sebagai agama yang hanya berorientasi kepada ritual. Dikotomi ini ternyata juga berimplikasi kepada dikotomi dalam sistem pendidikan, dalam bentuk modern dan tradisional. Sebagai proses yang memiliki continuity dan secara sadar dilakukan untuk mempersiapkan generasi yang memiliki pengetahuan dan nilai secara seimbang, berbagai unsur pada pendidikan harus terus menjaga keterkaitan yang telah ada untuk mencapai tujuan yang telah ditetapkan. Partisipasi dan kepedulian masyarakat yang masih rendah terhadap kemajuan dunia pendidikan harus diakhiri, seiring realisasi konsep school based management atau SBM.

Aspek lain yang harus disiapkan adalah kualitas guru. Secara konsepsional, guru memiliki tiga fungsi, yaitu kognitif, moral dan inovatif. Agar

\footnotetext{
${ }^{20}$ IR. Poedjawijatna, Pembimbing ke Arah Alam Filsafat (Jakarta : Rineka Cipta, 1997), 201203.

${ }^{21}$ Ibid, $187-190$
} 
menjadi sosok ideal di Indonesia, guru harus memenuhi delapan indikator, yaitu prinsip teologis, prinsip formal, prinsip fungsional, prinsip kultural, prinsip komprehensivitas, prinsip subtstansial, prinsip sosial dan prinsip identitas. Urgensi untuk melakukan reformasi terhadap filsafat pendidikan, sebagai dasar dari sistem pendidikan yang dilaksanakan di Indonesia selama ini, merupakan suatu keharusan. Hal ini didasarkan kepada kenyataan bahwa filsafat merupakan dasar perilaku seseorang dan juga suatu bangsa. Penyusunan teori pendidikan yang baru diharapkan supaya pelaksanaan pendidikan lebih terarah dan sistematis dalam mewujudkan tujuannya. Teori pendidikan ini harus dirumuskan dengan tetap mempertimbangkan berbagai aspek yang terdapat dalam pendidikan itu sendiri, seperti pendidik, peserta didik, kurikulum, fasilitas, manajemen, materi pembelajaran dan sebagainya.

\section{DAFTAR PUSTAKA}

Abdul Muta'al Al-Sha'idy, Al-Mujaddidun fil Islam (Kairo: Darul Hamam lil Thaba'ah, tt.).

Ali Ashraf dan Sajjad Husain, Crisis in Muslim Education (Jeddah: King Abdulaziz University Press, 1979).

A. Syafiq Mughni, Dinamika Intelektual Islam Pada Abad Kegelapan(Surabaya: LPAM, 2002).

Ali Maksum dan Luluk Yunan Ruhendi, Paradigma Pendidikan Universal di Era Modern dan Post-Modern (Yogyakarta: Ircisod, 2004).

Harun Nasution, Pembaharuan Dalam Islam (Jakarta: Bulan Bintang, 1992).

Jurgen Habermas, "Modernity: an Unfinished Project," dalam The Post-Modern Reader, ed. Charles Jencks (New York: St. Martins Press, 1992).

Jeanne S. Mintz, Muhammad, Marx, Marhaen; Akar Sosialisme di Indonesia, terj. Zulhilmiyasari (Yogyakarta: Pustaka Pelajar, 2002).

John Naisbit dan Patricia Aburdence, Megatrend 2000 (London: Sidwick, 1990).

Karen Armstrong, A History of God (New York: Ballantine Books, 1993).

Louis O Kattsoff, Pengantar Filsafat, terj. Soerjono Soemargono (Yogyakara: Tiara Wacana, 1994).

Mukani, Pergulatan Ideologis Pendidikan Islam (Malang: Madani Media, 2011).

"Mendamba Guru Ideal Perspektif Kota Santri," Rakyat Post, 16 Juli 2009.

"'Minim Karya Tapi Karya Gelar,” Rakyat Post, 1 Desember 2011.

, "Guru Bermutu dari Program Master Teacher," Majalah Media, Maret 2013.

, "Ironi, Pendidik Jombang Menjiplak Disertasi," Majalah Suara Pendidikan, No. 6, Pebruari 2013.

, "Guru Profesional Tak Cuma Tumpuk Portofolio," Majalah Media, Oktober 2012.

"Character Education di Indonesia," Jurnal Islamica, Vol. 1 No. 2,

Maret 2007 (Surabaya: Program Pascasarjana IAIN Sunan Ampel). 

6.

Nurul Yani, "Ijasah Instan dan Mental Pragmatis Guru," Majalah Media, Desember 2013.

Osman Bakar, Tauhid dan Sains, terj. Yuliani Liputo (Bandung: Pustaka Hidayah, 1994).

Poedjawijatna, Pembimbing ke Arah Alam Filsafat (Jakarta: Rineka Cipta, 1997). 